\title{
RELATED PARTY TRANSACTIONS - OVERVIEW
}

\author{
Alexandra Corlaciu ${ }^{1}$ \\ Adriana Tiron Tudor ${ }^{2}$
}

\begin{abstract}
The purpose of the present investigation is to provide a short overview of the main implications arising from carrying related parties transactions: accounting reporting (related party disclosures - IAS 24), auditing (audit procedures for related party transactions), taxation (issues regarding the transfer prices used for intra-group transactions). Although this research does not identify a problem with the scope to solve it however the utility might be observed by its contribution to the future developments, by providing premises for forthcoming studies in the "related party transactions" field.
\end{abstract}

Key words: Related party transactions, related party disclosures, transfer pricing

JEL Codes: M41, M42, H25, H26

\section{Introduction}

The role of transnational companies in the world economy has grown significantly in recent decades. This situation is due to globalization and partly reflects the trend of national economies integration and the technological progress. As a result of multinationals expansion, the intra-group commercial transactions have significantly increased (the UNCTAD report from 2003 shows that more than $60 \%$ of international trade took place within multinationals).

Related party relationships are a normal feature of business, because many entities frequently carry on their activities through subsidiaries, joint ventures and associates. In such circumstances, an entity is able to influence financial and operating policies of the entity which has invested in, through control, joint control or significant influence. Relationship with related parties may have significant effects on the result and financial position of an entity because the parties can enter into transactions that independent entities would not be. Moreover, financial position and results of an entity may be affected by the mere existence of related parties, even if there are no transactions between them. Therefore, knowledge of transactions, outstanding balances, including commitments and relationships with related parties can affect the way in which the financial statement users might assess the performance, financial position, risks and opportunities of an entity.

The related party transactions are very important for a company, as they have a lot of implications in various fields, such us: accounting reporting, auditing, tax compliance, strategic management, corporate governance etc. This paper is aiming to provide an overview about the first three fields mentioned above. We choose to analyze these fields (i.e. accounting, audit, tax) as they are external factors - rules provided by competent authorities - with important influence for multinationals activity. A company does not have any capacity to control the accounting, audit and

\footnotetext{
${ }^{1}$ Babes - Bolyai University, Faculty of Economics and Business Administration, Cluj-Napoca, Romania, e-mail: alexandracorlaciu@yahoo.com

${ }^{2}$ Babes - Bolyai University, Faculty of Economic Sciences and Business Administration, Cluj Napoca, Romania, e-mail: adriana.tiron.tudor@gmail.com.
} 
tax regulations and it always has to conduct its activity in order to be in compliance with such legislative requirements.

\section{Research methodology}

The purpose of the present investigation is to provide a short overview of the main implications arising from carrying related parties transactions: accounting reporting (related party disclosures - IAS 24), auditing (audit procedures for related party transactions), taxation (issues regarding the transfer pricing used for intra-group transactions). We choose to discuss about these three fields as they are external factors (rules provided by competent authorities) with high influence for multinationals activity. We used in this paper the fundamental research type and we applied the deductive research method (meaning that general conclusions were extracted based on available data). As investigation techniques, we used the literature research; analysis of international regulations/law in accounting, audit, taxation; logical analysis.

Although this investigation does not identify a problem with the scope to solve it however the utility might be observed in its contribution to the future developments, by providing premises for forthcoming studies in the "related party transactions" field.

\section{Literature review}

A related party transaction is defined by International Accounting Standard (IAS) 24 as follows: "a transfer of resources, services, or obligations between related parties, regardless of whether a price is charged", and two or more parties are considered to be related if one of them has the ability to control, joint control or to exercise significant influence over the other one in making operational or financial decisions.

By conducting a literature review, Chen-Wen et. Chinsun (2010) have found out that related party transactions are broadly defined in two ways, as described hereinafter. Thus, generically, related party transactions are defined as transactions between a company and its related entities (e.g., affiliates, subsidiaries, principal owners, directors, officers). Then, related-party transactions are defined by Young (2005) as "transactions between a company and an insider, which have been the subject of heightened scrutiny from investors and the financial media since the collapse of Enron in late 2001". In a paper about the techniques used for auditing related party transactions Gordon et al. (2007) state that related party definition varies across regulatory bodies. Furthermore, they consider that related party transactions ought to be assessed in the overall context of a company's governance structure, where the managements' assertions regarding the existence and the nature of such transactions should play a determinant role.

In the opinion of Coase (1937), related party transactions between group members might be cost-effective, due to two main reasons: they help in reducing transaction costs and enhance the enforcement of contracts and property rights. However, the principal owners and/or main directors might abuse from such related flows by using them for opportunistic purposes. A relevant example is when transactions are carried out at a different price than the market one and the profits are then shifted among group members, while the consolidated earnings remain generally unaffected (Thomas et al., 2004). Gordon et al. (2007) considered that related party transactions represent a normal part of the business and the fact that firms are conducting a high volume of such transactions should not automatically lead to the conclusion that they hide accounting and financial fraud.

According to literature review, the papers regarding transfer pricing generally deals with the following main topics: tax accounting papers studying the degree to which differentials between national tax rates lead to income shifting and transfer pricing manipulation (Klassen, Lang, Wolfson, 1993; Harris, 1993; Iacob, 1996; Swenson, 2001; Gupta, Mills, 2002); fiscal rules as one of the environmental factors that influence the group's transfer pricing policy (Emmanuel, Mehafdi, 
1994; Cravens, Shearon, 1996; Cravens, 1997); optimal transfer pricing method from a tax perspective (Swenson, 2001; Van Mens, Porquet, 2001; Douvier, 2005); the possibilities to maximize the firm's value through the transfer pricing strategy (Michaels, 2005). There are a lot of papers investigating the relationship between company performance and related party transactions (Igor et al., 2001; Grosfeld and Tressel, 2002; Ming and Wong, 2003; Young, 2005; Bennedsen et al., 2007). Gordon et al (2004a) and Kohlbeck and Mayhew (2004) conclude that a weak corporate governance leads to more related party transactions.

Generally, in the scientific literature on the related party transactions topic, two theories predominate, as follows: (a) conflict of interests: in this case the transactions are viewed as potentially harmful and they are thought to be carried out in the executives interest (with the purpose to expropriate wealth from shareholders) - Jian and Wong (2008); Aharony et al. (2005), Kohlbeck and Mayhew (2004) etc; (b) efficient transaction: related party transactions are considered profitable economic deals - Gordon et al. (2004 a, b).

\section{Accounting overview}

The general reporting framework of related party transactions is set out by IAS 24 . Related party transactions can take a variety of forms. Many of them include transactions in the normal course of business, for example, purchases or sales of goods at market values. However, others can include significant one-off transactions that may be at a fair value on an arm's length basis or that may be at book value or some other amount that differs from market prices. The stated objective of IAS 24, "Related party disclosures", is to ensure that "financial statements contain the disclosures necessary to draw attention to the possibility that the reported financial position and results may have been affected by the existence of related parties, transactions or outstanding balances with such parties" (IAS 24 par 1).

Most related party transactions are carried out in the normal course of an entity's business, but companies do also sometimes act improperly or illegally through the medium of related parties (this is particularly in those circumstances when disclosure is important). Of course, it would be naive to think that an entity that indulged in improper or illegal activities would willingly disclose the fact. The disclosure requirements of IAS 24 cannot prevent illegal actions or fraud. However, the existence of rules in the standard gives authority to both employees involved in preparing the financial statements, and to auditors, to resist any suppression of disclosure. In addition, regulators and other authorities are able to use the standard's provisions when investigating and punishing any illegality revealed.

IAS 24 is a disclosure standard. It sets out how related party relationships, transactions and balances should be identified and what disclosures should be made, and when. (IAS 24 par 2). The standard requires disclosure of related party transactions and balances in the individual financial statements of parent companies and subsidiaries. This means that intra-group transactions between such entities are disclosed, although generally such disclosures are likely to be aggregated by type because of their large volume. For instance, a subsidiary would usually disclose aggregate sales to, and aggregate purchases from, its parent. On consolidation, however, such transactions would be eliminated and would, therefore, not be disclosed in the consolidated financial statements (IAS 24 par 3, 4).

The standard also requires that related party relationship, transactions and balances between a venturer, an investor in a joint venture or an associate and its joint venture or associate to be disclosed in the individual financial statements of both the investor and associate (IAS 24 par 3 ). As such, transactions and balances that are not eliminated on consolidation would also be disclosed in any consolidated financial statements produced by the investor.

There are no exemptions from disclosure of intra-group transactions for subsidiaries, or for parent companies that produce consolidated financial statements with their individual financial 
statements. Nor is there any "confidentiality" exemption, even in the situation where an entity has a duty of confidentiality imposed by law. In relation to intra-group transactions between parents and subsidiaries, the IASB has stated that disclosure of related party transactions and balances is essential information for external parties who need to be aware of the level of support provided by related parties (IAS 24 par BC11). Many subsidiaries, for example, depend on financial support from their parents and those who advance credit to such subsidiaries should to be aware of the level of support available from the parent or of the lack of such support.

\section{Auditing overview}

The related party transactions audit represents an important part of a financial statements audit. The detection of related parties and related party transactions as well are between the most important and difficult issues of a financial statements audit. This part of an audit is fateful because of the following reasons: (i) the demand under generally accepted accounting standards to present material related party transactions and particular control relationships; (ii) the possibility to distort or mislead the financial statements in the lack of appropriate disclosure; and (iii) the evidences of fraudulent financial reporting and/or misappropriation of assets which were encouraged, among others, by the existence of undisclosed related parties. The undisclosed related parties are important tools for unscrupulous persons. Related parties, such as affiliated entities, controlling shareholders or general management may perform transactions that improperly grow earnings by distorting their economic substance or mask financial results through lack of disclosure, or may even fraud the company by transferring funds to other related parties.

Related party transactions have been playing an important role in auditing in the latest years. From an auditor's point of view, related-party transactions bear two different, but not necessary exclusive, implications: appropriate disclosure and fraud detection. In certain situations, relatedparty transactions might be the direct result of an affiliation/controlling relationship, as in the lack of such relationship, the dealings might not have occurred at all or might have had substantially different conditions. In such circumstances, disclosure regarding the amount and the nature of related party transactions is necessary for a suitable understanding of the financial statements. Inappropriate disclosure of transactions with related parties might have as a result the misleading of the financial statements and this is way the auditor should be concerned with identifying such transactions during the audit process and evaluating the veracity of their disclosure.

The general framework regarding the responsibilities of the auditor with respect to the related party relationships and transactions during a financial statements audit is provided by the International Standard on Auditing (ISA) 550 "Related parties". According to its provisions, the auditor has the responsibility to perform "audit procedures to identify, assess and respond to the risks of material misstatement arising from the entity's failure to appropriately accounting for or disclose related party relationships, transactions or balances in accordance with the requirements of the financial reporting framework basis on which the reporting statements are performed" (ISA 550, par 3). The auditor has to achieve a proper understanding of an entity's related party relationship and transactions in each auditing process, even in the cases when the applicable financial reporting framework requires minimal or no related party disclosures, as the auditor needs to be able to assess whether the financial statements are affected by those relationships and transactions (ISA 550 par 4).

Where there is observed a material misstatement of the financial statements that belong to the non-disclosure of information, the auditor is guided by the requirements of ISA 705, "Modifications to the opinion in the independent auditor's report", which is applicable for periods starting on or after 15 December 2009. Paragraph 19 of ISA 705 states that where such circumstances arise, the auditor should: (i) "discuss the non-disclosure with those charged with governance; (ii) describe in the basis for modification paragraph the nature of the omitted information; and (iii) unless prohibited by law or regulation include the omitted disclosures 
provided it is practicable to do so and the auditor has obtained sufficient appropriate audit evidence about the omitted information" (ISA 705 par 19).

The previous auditing standard, for periods starting prior to 15 December 2009, did not require the auditor to include the missing disclosures where appropriate. This means that for periods starting on or after 15 December 2009 audit opinions might include the omitted disclosures where previously the auditor simply gave a qualified opinion and stated the company's failure to disclose the information.

The ISA's application guidance describes circumstances where it would not be appropriate to disclose the omitted information as follows: "(i) the disclosures have not been prepared by management or the disclosures are otherwise not readily available to the auditor; or (ii) in the auditor's judgment the disclosures would be unduly voluminous in relation to the auditor's report." (ISA 705 par A19).

\section{Fiscal overview}

From a fiscal point of view the related party transactions present importance due to the transfer prices involved. In the cases when one part of a transnational company situated in one country transfers (meaning that it sells) goods, services or know-how to another part situated in a different country, the price paid for these goods or services is called "transfer price". This is considered as the price charged in commercial dealings (whether for tangible property, intellectual property or services provision) carried on between companies under control/affiliation relationship (Abdallah, 2004) and is often an important component used for performance assessing within large divided companies (Langfield-Smith, Smith, 2005).

Transfer pricing is one of the most challenging and frequently least understood tool of a transnational company. In unrelated party transactions, the independent market forces set the commercial pricing of goods, intangibles or services transacted between them. However, due to the lack of independence belonging to the commercial and financial transactions carried on between related parties, there is the possibility of setting transfer prices that deviate from independent commercial prices.

As a consequence, this might result in the distortion of profits and tax liabilities as well in case of each related entity. When the related entities are situated in different fiscal jurisdictions, the potential distortion of profits and tax liabilities involves a greater concern, due to the fact that the difference in taxation level might lead to the possibility of not paying the fair share of tax in certain jurisdictions, while the group as a whole can benefit from a tax advantage.

Thus, transfer pricing might be just an arbitrary figure, meaning by this that it could be unrelated to costs incurred, to operations carried out or to added value. The transfer prices might be shaped at a level which reduces or even cancels out the total tax that has to be paid by the transnational organisation in certain tax jurisdictions.

Based on the above, we can conclude that the growth of multinationals bear increasingly complex taxation aspects for both companies and tax administrations, since different country rules for the company taxation cannot be view in isolation, but must be analyzed in a broad international context. These issues arise from the practical difficulty for both multinationals and tax administration to determine the revenues and expenses of a company that is part of a transnational group that should be taken into account within a fiscal jurisdiction, particularly where the group's operations are highly integrated.

In the case of multinationals, the need to comply with regulations and administrative requirements that might differ from country to country involves additional problems. Different requirements might lead to a greater burden on a company and result in higher cost compliance than for a similar firm operating only within a single tax jurisdiction. 
For tax administration, specific problems may arise at both policy and practical level. At a policy level, countries have to reconcile their legitimate right to tax profits of a taxpayer based upon revenues and expenses that might be reasonably considered arising within their territory with the necessity to avoid the taxation of the same piece of income by more than one tax jurisdiction. Such double or multiple taxation might create an impediment to cross-border transactions of goods, services and capital movement. At a practical level, a country's determination of such revenues and expenses allocation could be impeded by difficulties in obtaining pertinent data located outside its own jurisdiction.

Thus, in a global economy where multinationals play a prominent role, governments should ensure that the taxable profits of such an entity are not artificially shifted out of their country and that the tax base reported by multinationals within their jurisdiction reflects the real economic activity performed therein. This is way the tax authorities in the US and a handful of others countries has started to pay considerable attention to transfer pricing early before, in the 1960 and 1970. As part of their general remit OECD member countries recognised that it would be helpful to provide some general guidance on transfer pricing in order to avoid the damaging effect that double taxation would have on international trade. The result was the OECD report and Guidelines of transfer pricing which were first issued in 1979 and were subsequently revised and updated in 1995 and again in 2010 .

The OECD Guidelines for transfer pricing provides "the arm's length principle" as the standard to guide transfer pricing. Currently, the arm's length principle is the internationally accepted standard adopted by the OECD's member countries and many non-member countries as well.

The arm's length principle is defined in paragraph 1 of Article 9 (Associated Enterprises) of the OECD Model Tax Convention on Income and Capital as presented below: "Where conditions are made or imposed between two affiliated enterprises in their commercial or financial relations which differ from those which would be made between independent enterprises, then any profits which would, but for those conditions, have accrued to one of the enterprises, but, by reason of those conditions, have not so accrued, may be included in the profits of that enterprise and taxed accordingly."

Article 7 "Business Profits" of the OECD Model Tax Convention on Income and Capital provides under paragraph 2 that when the profits are attributed to a permanent establishment, that permanent establishment should be considered as "a distinct and separate enterprise engaged in the same or similar activities and under the same or similar conditions". These provisions correspond to the application of the arm's length principle defined in paragraph 1 of Article 9 "Associated Enterprises" of the OECD Model Tax Convention on Income and on Capital.

According to the arm's length principle, the transactions between related parties should be performed under comparable conditions and circumstances as the transaction with independent parties. This principle is based on the hypothesis that whether the terms and conditions agreed in an independent party transaction are driven by the market forces, the pricing of the transaction would reflect the real economic value of the contribution of each entity involved in the transaction. Shortly, this means that whether two related parties obtain profits at levels above or below the comparable market level just due to the special relationship between them, the profits will be considered as non-arm's length. In such a situation, tax authorities that enact the arm's length principle are allowed to make all the needed adjustments to the taxable profits of the related parties in their countries with the scope to reflect the real value that would be derived on an arm's length basis.

Hereby, by applying the arm's length principle, the related and the independent party dealings would be treated equally for tax purposes and hence the creation of tax advantages or disadvantages would be avoid (otherwise the relative competitive positions of each entity would be distort). 
However the application of the arm's length principle is not simple and it involves certain difficulties. For instance, there are cases of complicated and unique business structures or arrangements that might be rarely encountered between independent entities. The lack of comparable circumstances incurred between independent parties leads to a difficult application of the arm's length principle. Moreover, in order to establish the arm's length principle, there would be sometimes necessary substantial analysis of large volumes of data and information (in addition, there are cases when certain information might not even be readily available or might be confidential and cannot be disclosed without revealing business secrets). Furthermore, the taxpayers could be obliged to bear additional burdens in order to perform such comprehensive analyses for applying the arm's length principle and preparing sufficient documentation needed to demonstrate compliance with the arm's length principle.

Nevertheless, the multinationals should carefully treat the transfer pricing issues and should ensure they hold a proper and detailed documentation of transfer prices used, as it is vital for every entity to hold a coherent and defendable transfer pricing policy, which is responsive to the very real climate of change in which they are operating. As cross border intra-group transactions are growing rapidly and becoming more and more complex, the tax authorities worldwide become more vigilant. Thus, currently they are imposing stricter penalties and new documentation requirements and are engaging in increased information exchanges and increased tax audit/tax inspection processes, as they become aware of how transfer pricing might affect tax incomes. By considering transfer pricing practices carefully, multinational groups have the possibility to manage risk while improving operational and financial performance based on a long-term view of sustainable growth.

\section{Conclusions}

As the economy globalize, the numerous processes in the research and development, manufacture, sale and distribution of goods or services increasingly are performed by separate entities within a multinational group and the flow of products and services through intercompany transactions frequently involves two or more countries. In these circumstances, the related party transactions become very important for a company, all the more so as they bear a lot of implications in various fields.

Generally, in the scientific literature on the related party transactions topic, two theories predominate, as follows: (a) conflict of interests: in this case the transactions are viewed as potentially harmful and they are thought to be carried out in the executives interest (with the purpose to expropriate wealth from shareholders) - Jian and Wong (2008); Aharony et al. (2005), Kohlbeck and Mayhew (2004) etc; (b) efficient transaction: related party transactions are considered profitable economic deals - Gordon et al. (2004 a, b).

An important issue arising from carrying out related party transaction is represented by the transfer prices involved in such dealings. These prices are not the subject of an exact science and, consequently, their determination is a subjective issue, which can give rise to different interpretations. The transfer pricing assessment is a laborious process which requires tax and accounting knowledge and also needs information from various economic fields that may influence their level. Such information is about: a very good knowledge of the goods/services traded, of the production process of these goods/services, of the market etc.

By using the fundamental research type, this paper provided a short overview of accounting, auditing and taxation aspects borne by the related party transactions. As it is presented above, those are complex fields involving specific and different burdens in a company's account. Consequently, the firms carrying out related party transaction must be aware of these provisions in order to ensure themselves a sustainable growth, to maintain competitive advantage and create value for shareholders. 


\section{References}

1. Chen-Wen C., Chinshun W., 2010. Related Party Transactions and Ownership Concentration: Theory and Evidence, http://www.g-casa.com/conferences/singapore/ papers_in_pdf/wed/Chen.pdf, accessed 27.09.2011;

2. Cheng P., Chen J, 2006. Related Party Transactions, Expropriation and Post-IPO Performance - Chinese Evidence, http://efmaefm.org/Symposium2007/peng.pdf, accessed 27.09.2011;

3. Gordon, E., Henry E., Lauwers T., Reed B., 2007. Auditing related party transactions: A literature overview and research synthesis, Account. Horizons, 21: 81-102. DOI: 10.2308/ACCH.2007.21.1.81;

4. Ken Y., Chen R., 2007. Fraud Risk Factors and the Likelihood of Fraudulent Financial Reporting: Evidence from Statement on Auditing Standards No. 43 in Taiwan, http://aaahq.org/audit/midyear/08midyear/papers/53_Chen_FraudRiskFactors.pdf - accessed 28.09.2011;

5. Moscariello N., 2011. Related party transactions in continental European countries: Evidence from Italy, International Journal of Disclosure and Governance, Palgrave Journal;

6. OECD, 2010. Transfer pricing guidelines for multinational enterprises and tax administration, Paris;

7. PricewaterhouseCoopers, 2011. International transfer pricing;

8. Stauropoulos A., Samaras I., Arsenos P., 2011. The Effect of the International Accounting Standards on the Related Party Transactions Disclosure, American Journal of Applied Sciences, 8 (2): 156-163;

9. Tomkins C., McAulay L., 1992. A review of the Contemporary Transfer Pricing Literature with Recommendations for Future Research, British Journal of Management, Volume: 3, Issue: 2, Publisher: Wiley Online Library, Pages: 101-122. 